\title{
POLITIK IDENTITAS DAN MITOS PEMILIH RASIONAL*
}

\section{Burhanuddin Muhtadi}

Pengajar FISIP UIN Syarif Hidayatullah Jakarta

dan Direktur Indikator Politik Indonesia

\section{Abstrak}

Perilaku memilih merupakan gejala yang kompleks. Keputusan memilih ditentukan oleh banyak faktor. Seorang calon yang berasal dari kelompok identitas primordial tertentu belum tentu dapat menarik suara mayoritas di kelompoknya sendiri. Hal ini bisa terjadi karena, selain faktor identitas, pemilih juga mempertimbangkan faktor-faktor lain, terutama kualitas personal calon. Intinya, dinamika politik lokal seringkali membuka ruang mobilisasi politik identitas. Secara umum, penelitian ini telah menemukan bukti empiris bahwa agama dan etnis yang menjadi bahan bakar politik identitas merupakan faktor yang penting dalam pemilihan kepala daerah.

Kata Kunci : Politik identitas, politik lokal, politik elektoral, Ormas Islam, Pilkada

Koran San Francisco Chronicle memasang headline bertajuk "Bradley Win Projected" pada 3 November 1982, sehari setelah pemilihan Gubernur California, Amerika Serikat. Keberanian San Francisco Chronicle mengumumkan Tom Bradley -eks Walikota Los Angeles berkulit hitam yang popular dan maju sebagai Gubernur dari Partai Demokrat- sebagai pemenang sebelum penghitungan resmi diumumkan memang bukan tanpa alasan. Survei-survei dan exit poll juga memprediksi Tom Bradley bakal memenangi pemilu dengan selisih besar. Hasil resmi menunjukkan sebaliknya. George Deukmejian, calon dari Partai Republik yang berkulit putih, yang justru menjadi pemenang. Charles Henry (1983) menemukan faktor ras di balik kekalahan Bradley. Banyak warga California yang keberatan memilih Bradley karena ia berkulit legam. Ahli survei mengenangnya sebagai Bradley effect, ketika warga kulit putih saat disurvei menyembunyikan antipatinya kepada Bradley karena takut dituding rasis.

* Tulisan ini adalah pengembangan dari kolom penulis bertajuk "Mitos Pemilih Jakarta Rasional?" yang dimuat Majalah Tempo pada 27 Februari 2017 dan "Ahok's satisfied non-voters: an anatomy" (Mietzner dan Muhtadi) yang dimuat New Mandala, 5 Mei 2017. 
Sebagian kalangan menduga Bradley effect terjadi dalam pemilihan gubernur di DKI Jakarta pada 2017 lalu. Mereka mengaitkan dengan prediksi sebagian survei yang menunjukkan kemenangan Basuki Tjahaja Purnama (Ahok). Argumen mereka sebagian responden mengaku ke surveyor bakal memilih Ahok, tapi pas di Hari H mereka urung memilih Ahok karena faktor agama dan etnik. Namun jika Bradley effect benar terjadi di Jakarta, mengapa sebagian lembaga survei sukses memprediksi Ahok unggul, meski selisih suara dengan Anies Baswedan tak selebar yang mereka prediksi?

Beberapa pihak yang menduga Bradley effect mungkin terjadi di Jakarta biasanya menyebut dua hipotesis. Pertama, kesenjangan (gap) antara tingkat kepuasan kinerja (approval rating) dan elektabilitas Ahok terjadi jauh sebelum kasus Al-Maidah meledak. Survei Indikator Politik Indonesia pada Januari 2016 menunjukkan 74 persen warga puas atas kinerja Ahok, tapi "hanya" 48 persen yang sudi memilihnya. Pada survei Indikator Mei-Juni 2016, approval rating Ahok mencapai 76 persen, tapi kedipilihannya "hanya" 53 persen. Sebelum insiden pidato Ahok mengenai Al-Maidah 51, selalu ada gap antara yang puas dengan tingkat kedipilihan Ahok. Dengan kata lain, tidak seluruh yang puas atas kinerja Ahok sebagai petahana berkenan memilihnya. Survei eksperimen Indikator pada Januari 2016 juga menemukan etnis dan agama merupakan faktor yang dipertimbangkan penduduk dalam menentukan pilihan. Desain eksperimen juga memberi informasi berharga bahwa "kesamaan agama" lebih dipertimbangkan dibanding "kesamaan etnis".

Pidato kontroversial Ahok tentang Al-Maidah 51 pada 27 September 2016 membuka kotak pandora dan menjustifikasi apa yang selama ini disimpan rapat-rapat di bawah telapak meja. Intinya, sebelum muncul penantang secara definitif pun politik identitas diam-diam sudah bekerja. Mereka mengakui Ahok sudah bekerja baik, tapi hati mereka sulit menerima karena dia dianggap sebagai representasi yang liyan (representation of "the Others")-meminjam istilah Christoffanini (2003). Ahok menyandang dua lapis minoritas sekaligus: Kristen dan Tionghoa. Jangankan di kalangan Muslim konservatif, di sebagian kalangan moderat pun terbersit kekhawatiran bahwa naiknya Ahok menjadi sinyal dominasi minoritas yang sebelumnya dianggap sudah merajai ekonomi dan kini merambah ke politik. Ketika Ahok meroket, ada perasaan di sebagian kalangan bahwa domain politik yang dianggap menjadi kaveling eksklusif mereka terancam. Inilah yang dalam literatur post-kolonial disebut stereotip, yakni "a preconceived and oversimplified idea of the characteristics which typify a person, situation, etc. an attitude based on such a preconception" (Felsenstein, 1995: 11). 
Kemungkinan kedua yang bisa mengonfirmasi Bradley effect adalah faktor agama yang diduga memiliki efek elektoral yang tak sekecil yang diprediksi sebagian kalangan. Eep Saefullah Fatah misalnya, menyimpulkan agama bukanlah faktor utama pilkada Jakarta dengan bersandar pada alasan bahwa sebagian besar responden memilih bukan berdasarkan agama. Dengan bersandar pada temuan exit poll yang digelar PolMark, Eep mengatakan hanya 22 persen warga Jakarta yang memilih Anies-Sandi karena kesamaan agama. Artinya, kata Eep lebih lanjut, 36 persen pemilih Anies-Sandi memilih bukan karena faktor agama (Kompas.com, 22/4/2017). ${ }^{104}$ Tapi, perlu diingat, pertanyaan seperti ini sebenarnya rentan terdistorsi social desirability bias, yakni alasan memilih karena faktor agama dianggap secara normatif atau politik "kurang elok" (politically incorrect). Sebaliknya, memilih berdasarkan program terlihat lebih intelek. Bisa jadi, ketika ditanya secara langsung, responden menyembunyikan pilihan karena diam-diam mengakui bahwa pilihan atas dasar tersinggung ucapan Ahok soal Al-Maidah mungkin kurang "heroik".

Analisis regresi logistik multinomial berdasar data longitudinal yang dimiliki Indikator misalnya, menyediakan jawaban lain dengan mengestimasi signifikansi sebuah variabel independen setelah dikontrol oleh variabel-variabel yang lain. Hasilnya, kasus Al-Maidah terbukti terus membayangi elektabilitas Ahok. Ini menjelaskan mengapa Anies paling banyak mendapat aliran suara pemilih mengambang (undecided voters). Intinya, Bradley effect bisa jadi membuat pemilih enggan menyatakan secara terbuka pilihan ke lawan Ahok. Pada saat survei mereka menyembunyikan jawabannya, atau mereka yang awalnya menyatakan memilih Ahok karena prestasi kerjanya berubah pikiran ketika berada di bilik suara mengingat latar belakang primordialnya yang berbeda dengan mayoritas warga.

\section{Politik Identitas dalam Kontestasi Elektoral}

Secara teoretik, banyak faktor yang menjelaskan elektabilitas pasangan calon kepala daerah, di antaranya model sosiologis, psikologis, dan rational choice atau pilihan rasional. Inti dari model sosiologis adalah kesamaan karakteristik sosial menentukan pilihan politik. Variabel sosiologis yang diyakini sebagai prediktor adalah agama, etnik, usia, gender, pendidikan dan pendapatan (Lazarsfeld, Berelson, dan Gaudet, 1944; Berelson, Lazarsfeld dan McPhee, 1954). Sebagai elemen penting dalam pembelahan sosial, agama dipercaya mempengaruhi perilaku pemilih. Lipset dan Rokkan (eds.), dalam Party Systems 
and Voter Alignments: Cross-National Perspectives (1967) misalnya, mengatakan ada korelasi signifikan antara afialiasi keagamaan dengan dukungan atas partaipartai konfesional di Eropa. Samuel Barnes (1974) juga menemukan bukti hubungan agama dengan perilaku pemilih di Italia. Arend Lijphart (1977) dalam Religious vs. Ethnic vs. Class Voting: The 'Crucial Experiment', menemukan bahwa dibanding variabel bahasa dan kelas sosial, agama lebih berpengaruh dalam menentukan pilihan partai di Belgia, Kanada, Afrika Selatan dan Swiss. Studi Norris dan Inglehart (2004), dalam Sacred and Secular: Religion and Politics Worldwide juga mengonfirmasi pengaruh agama dalam memilih.Intinya, model sosiologis ini kerap disebut sebagai pengejawantahan politik identitas dalam perilaku elektoral.

Adapun model psikologis menyatakan bahwa preferensi politik tidak ditentukan oleh variabel sosiologis demografis, tapi oleh faktor-faktor psikologis. Ukurannya adalah kedekatan dengan partai atau partisanship pengusung kandidat. Meskipun kedua kubu ini bertolak belakang, baik model sosiologis maupun psikologis sama-sama mengasumsikan bahwa isu atau program dalam kampanye bukan sebagai variabel penting. Sebaliknya, model pilihan rasional (rational choice) justru mengandaikan pentingnya program atau isu-isu teknokratik dalam menjelaskan elektabilitas calon. Dalam studi perilaku pemilih, evaluasi atas kinerja petahana adalah salah satu ukuran seberapa jauh model pilihan rasional bekerja. Kepuasan terhadap kinerja petahana menjadi dasar reward and punishment (Downs, 1957; Fiorina, 1981). Ukuran lainnya adalah retrospeksi egosentrik dan sosiotropik. Ukurannya adalah retrospeksi egosentrik dan sosiotropik. Selain itu, elektabilitas calon juga bisa ditentukan oleh kualitas personal calon seperti persepsi pemilih apakah calon jujur/bersih dari korupsi, mampu memimpin, perhatian terhadap rakyat, ramah dan santun, tegas dan berwibawa, pintar atau berwawasan dan berpenampilan menarik (Bean dan Mughan, 1989; Liddle dan Mujani, 2007; Miller dan Shanks, 1996).

Hasil pilkada DKI Jakarta 2017 memunculkan debat sejauhmana rasionalitas pemilih bekerja dalam menjelaskan perilaku pemilih. Menurut data longitudinal Indikator Politik Indonesia, rata-rata kepuasan publik terhadap Ahok mencapai 73,4 persen. Jika benar warga Jakarta rasional, seharusnya Ahok minimal mengantongi suara 70 persen sesuai dengan proporsi warga yang puas terhadap kinerjanya, tapi di putaran kedua Ahok-Djarot kalah telak dan hanya mengantongi suara sebesar 42 persen. Dengan kata lain, perolehan suara pasangan calon di Jakarta tidak bisa dijelaskan semata-mata oleh faktor rasionalitas. 
Tabel 1: Alasan Memilih di Pilkada DKI Jakarta Putaran Kedua

\begin{tabular}{|c|c|c|c|}
\hline alasan_Col_PCT & Base & Ahok-Djarot & Anies-Sandiaga \\
\hline Agamanya sama dengan saya & 34.9 & 2 & 57 \\
\hline Berasal dari keluarga tokoh politik/masyarakat & 0.5 & 1 & 0 \\
\hline Berasal dari partai yang saya dukung & 0.8 & 1 & 1 \\
\hline Ikut pilihan orang lain/keluarga/warga sekitar & 1.7 & 3 & 1 \\
\hline Berpengalaman di pemerintahan & 9.0 & 17 & 3 \\
\hline Orangnya jujur/bersih dari praktek KKN & 6.0 & 12 & 2 \\
\hline Orangnya perhatian pada rakyat & 6.0 & 6 & 6 \\
\hline Orangnya pintar/berpendidikan & 4.1 & 1 & 8 \\
\hline Orangnya tegas/berwibawa & 3.6 & 7 & 1 \\
\hline Orangnya ramah/santun & 2.5 & 0 & 4 \\
\hline Program-program yang dijalankan atau dijanjikan paling meyakinkan & 7.2 & 8 & 8 \\
\hline Bisa membawa perubahan & 8.7 & 7 & 10 \\
\hline Sudah ada bukti nyata hasil kerjanya & 13.2 & 32 & 1 \\
\hline Pernah bertemu langsung & 0.0 & 0 & 0 \\
\hline Tokoh partai politik & 0.1 & 0 & 0 \\
\hline Lainnya & 1.0 & 1 & 1 \\
\hline $\mathrm{TT} / \mathrm{T} \mathrm{J}$ & 0.6 & 1 & 0 \\
\hline
\end{tabular}

Inilah anomali politik elektoral. Pada umumnya terdapat korelasi yang sangat konsisten dan kuat antara kinerja petahana dengan tingkat kedipilihan. Secara rasional, warga mengakui kinerja Ahok dalam mengatasi banjir dan masalah sampah, meningkatkan pelayanan di kantor-kantor pemerintahan dan lain-lain. Meski masih belum puas dalam mengatasi kemacetan, warga juga melihat usaha konkret pemerintah provinsi dalam membangun sarana transportasi massal. Kekuatan Ahok-Djarot dalam aspek rasional juga diperkuat oleh performa mereka yang selalu dinilai terbaik dalam debat cagub-cawagub menurut persepsi publik. Pada survei Indikator awal Februari 2017, pada kelompok yang menonton acara debat cagub-cawagub, dukungan Ahok-Djarot signifikan lebih tinggi dibanding pada kelompok pemilih yang tidak menonton acara debat. Data exit poll Indikator putaran kedua juga menunjukkan bahwa warga yang memilih Ahok-Djarot sebagian besar karena faktor "sudah ada bukti hasil 
kerjanya" (32 persen), "berpengalaman di pemerintahan" (17 persen) atau “orangnya jujur bersih dari korupsi” (12 persen) (Tabel 1). ${ }^{105}$

Namun keunggulan Ahok pada aspek rasional tidak diikuti pada dimensi emosional. Ucapan kontroversial Ahok tentang Al-Maidah berpengaruh signifikan terhadap keputusan memilih pasangan calon gubernur-wakil gubernur. Pidato tersebut makin menambah antipati Ahok yang notabene berasal dari agama dan etnik minoritas. Mayoritas warga memutuskan pilihannya berdasarkan kesamaan agama. Apalagi, blunder tersebut diikuti dengan "polemik" dengan KH Ma'ruf Amin dalam persidangan turut meningkatkan kembali ketersinggungan pemilih Muslim. Survei Indikator pada Februari 2017, proporsi pemilih yang mengatakan Ahok menistakan agama dalam kasus AlMaidah 51 meningkat menjadi 57 persen dibanding pada Januari yang "hanya" 47 persen. Permintaan maaf dan tangis haru Ahok dalam pembukaan sidang kasus penodaan agama yang sempat menurunkan tensi kemarahan publik kembali meningkat tajam pasca-perdebatan dengan $\mathrm{KH}$ Ma'ruf di pengadilan.

\section{Anatomi Pemilih Puas Tapi Tak Memilih}

Meskipun Ahok kalah pada saat pencbolosan putaran kedua, 72 persen warga Jakarta masih mengaku puas atas kinerjanya. Namun, tingginya approval rating Ahok tidak otomatis mengangkat elektabilitasnya. Hal ini menjadi bukti bahwa "kepala” dan "hati” sebagian warga Jakarta terbelah. Mereka mengakui kinerja petahana baik, tetapi hati mereka sulit menerima Ahok. Inilah yang disebut George Orwell sebagai gejala doublethink yang dalam konteks ini dipahami sebagai "kemampuan seseorang untuk memercayai dua hal yang bertolak belakang secara bersamaan tanpa merasa bersalah atau tidak nyaman (disonansi kognitif)" (Alifia, 2016). Untuk itu penting membahas profil pemilih doublethink yang puas tapi tidak memilih Ahok ini karena menunjukkan menguatkan politik identitas dalam politik elektoral kita.

Data exit poll yang digelar Indikator Politik Indonesia, pemilih yang puas terhadap kinerja Ahok tapi tidak memilihnya mencapai 30,1 persen dari

105 Mengingat tulisan ini banyak mengacu hasil exit poll Indikator yang diselenggarakan pada Pilkada Jakarta putaran kedua tanggal 19 April 2017, maka saya akan mengulas metodologinya secara lengkap. Populasi exit poll adalah pemilih yang datang ke TPS dalam putaran kedua. Sampel dipilih dengan metode stratified two-stage random sampling. Stratifikasi dilakukan dengan mengelompokkan TPS menurut wilayah (kecamatan atau kelurahan). Langkah pertama: Di masing-masing wilayah dipilih TPS sebagai primary sampling unit secara random dengan jumlah proporsional. Langkah kedua: Di masing-masing TPS terpilih, dipilih dua orang pemilih yang baru keluar dari TPS pada waktu yang ditentukan secara acak. Responden terpilih diwawancarai lewat tatap muka oleh pewawancara yang telah dilatih. Responden yang berhasil diwawancarai sebanyak 798, response rate 99,75 persen. Dengan jumlah sampel sebanyak itu, toleransi kesalahan +_3,5 persen pada tingkat derajat kepercayaan 95 persen. 
total pemilih (Grafik 1). Dua kelompok lainnya tidak terlalu menarik diulas: 41,5 persen pemilih yang puas terhadap kinerja Ahok dan dengan suka cita mau memilihnya. Kelompok ini termasuk kalangan non-Muslim dan Muslim pluralis yang tidak melihat agama dan etnik Ahok sebagai pertimbangan utama dalam memilih. Kelompok pemilih sebesar 26,4 persen yang tidak puas terhadap performa Ahok dan karenanya tidak bersedia memilihnya juga tidak mengagetkan. Kategori ini mencakup Muslim konservatif yang sejak awal antipasti kepada Ahok dan warga Jakarta yang menolak kebijakan penggusuran, proyek reklamasi atau kebijakan pemerintah Jakarta lainnya yang memantik respon negatif.

\section{Grafik 1: Tiga Tipologi Pemilih Jakarta}



Secara analitik, dua kelompok terakhir ini kurang menarik diulas karena pilihan electoral mereka selaras dengan penilaian terhadap kinerja petahana, terlepas dari fakta bahwa kepuasan atau ketidakpuasan mereka juga dipengaruhi oleh faktor agama atau pertimbangan primordial lainnya. ${ }^{106}$ Selain itu, kedua kelompok -baik yang puas dan memilih Ahok atau mereka yang tidak puas dan tidak sudi memilihnya-bukanlah penentu hasil akhir pilkada DKI Jakarta. Sebaliknya, blok pemilih yang puas tapi tidak memilih Ahok, secara elektoral, sangat krusial. Jika mereka lebih mengedepankan "kepala" (baca: rasionalitasnya ketimbang identitasnya), maka Ahoklah yang akan memenangi laga. Sebaliknya, jika mereka lebih mengikuti kata "hati" (baca: aspek emosional dan primordialnya ketimbang kinerja positif Ahok sebagai petahana), maka Anieslah yang unggul. Oleh karena itu, sub-bagian ini kan mengulas anatomi

106 Data exit poll menunjukkan hampir seluruh pemilih non-Muslim Jakarta yang menggunakan hak suaranya pada putaran kedua menyatakan"sangat puas" atau "cukup puas" atas kinerja Ahok, dan "hanya" 67 persen Muslim yang "sangat atau cukup puas." 
pemilih yang mengalami doublethink ini, termasuk mengeksplorasi latar belakang demografi dan sikap keberagamaan mereka.

Hasil exit poll Indikator menemukan jenis pemilih yang puas tapi enggan memilih Ahok hampir seluruhnya beragama Islam (99 persen). Suku Betawi, Sunda, dan Minang lebih potensial mengalami doublethink. Dari segi usia, mereka kebanyakan datang dari pemilih muda (di bawah usia 26 tahun) dan tua (di atas 55 tahun). Dilihat dari latar belakang sosial ekonomi, kelompok pemilih jenis ini sekilas datang dari kalangan menengah ke bawah dan mayoritas tinggal di Jakarta Selatan dan Jakarta Timur. Meski karakteristik mereka ini cukup berbeda dengan sosio-demografi pemilih Ahok, secara umum informasi mengenai demografi mereka tak terlalu banyak membantu menjelaskan sikap dan perilaku mereka mengapa mereka puas tapi enggan memilih Ahok.

Perbedaan antara kelompok pemilih yang puas dan memilih Ahok, puas tapi tidak memilih, dan tidak puas dan tidak memilih makin kentara jika kita tilik dari sikap dan pandangan keagamaan mereka. Di kalangan pemilih yang puas tapi tidak memilih Ahok, 54,5 persen menjadikan agama sebagai pertimbangan utama dalam memilih; jauh lebih besar dari proporsi rata-rata warga Jakarta yang menjadikan agama sebagai konsideran dalam mencoblos (34,9 persen) (lihat Tabel 1). Selain faktor agama, tak ada alasan lain memilih Anies-Sandi yang signifikan; warga yang memilih pasangan tersebut karena dianggap mampu "membawa perubahan" hanya10 persen.

Tabel 2 menunjukkan bahwa mayoritas warga Jakarta sangat religius: 83 persen mengaku "selalu" atau "cukup sering" mempertimbangkan perintah atau nilai-nilai agama ketika membuat keputusan penting. Di antara mereka yang "selalu/sangat sering" menjadikan agama sebagai pedoman hidupnya, 42,7 persen responden mengaku puas tapi tidak memilih Ahok. Sementara, blok pemilih yang tidak puas dan enggan memilih Ahok jauh lebih religius: 62,2 persen mengaku menjadikan agama sebagai kompas hidupnya. Menariknya, pemilih yang puas dan memilih Ahok tak sesaleh kelompok pemilih lainnya. Demikian juga dengan pemilih Muslim yang merasa bagian dari ormas Islam maupun bukan, sebagian besar masuk kategori pemilih yang puas tapi tidak memilih Ahok, atau bahkan tak puas dan tidak memilihnya. Ini menunjukkan kemarahan pemilih Muslim merata di semua kalangan, termasuk di khalayak warga NU yang selama ini dikesankan lebih moderat ketimbang warga ormas Islam lain. 
Tabel 2: Nilai-nilai Agama dan Ormas Islam Berdasar Kinerja dan Pilihan Gubernur

\begin{tabular}{|c|c|c|c|c|c|}
\hline & Base & $\begin{array}{c}\text { Puas, } \\
\text { pilih Ahok }\end{array}$ & $\begin{array}{c}\text { Puas, } \\
\text { tidak pilih } \\
\text { Ahok }\end{array}$ & $\begin{array}{c}\text { Tidak } \\
\text { puas, } \\
\text { tidak pilih } \\
\text { Ahok }\end{array}$ & $\mathrm{TT} / \mathrm{T}$ \\
\hline & & 41.5 & 30.1 & 26.4 & 2.1 \\
\hline \multicolumn{6}{|c|}{ MEMPERTIMBANGKAN PERINTAH ATAU NILAI-NILAI AGAMA } \\
\hline Selalu/sangat sering & 44.9 & 35.6 & 42.7 & 62.2 & 42.0 \\
\hline Cukup sering & 38.2 & 37.7 & 43.4 & 33.1 & 36.7 \\
\hline Jarang & 10.6 & 15.0 & 10.9 & 3.7 & 6.0 \\
\hline Tidak pernah & 4.4 & 9.2 & 0.9 & 0.4 & 6.4 \\
\hline Tidak menjawab & 2.0 & 2.4 & 2.0 & 0.6 & 9.0 \\
\hline \multicolumn{6}{|c|}{ MERASA BAGIAN DARI O RMAS ISLAM } \\
\hline $\mathrm{NU}$ & 33.4 & 25.3 & 40.1 & 39.1 & 23.6 \\
\hline Muhammadiyah & 4.5 & 1.1 & 4.1 & 10.4 & 4.6 \\
\hline Ormas la innya & 3.0 & 1.3 & 3.0 & 4.2 & 19.5 \\
\hline Bukan bagian Ormas manapun & 39.1 & 31.3 & 46.9 & 42.5 & 39.0 \\
\hline Tidak menjawab & 4.3 & 5.1 & 4.8 & 2.5 & 5.8 \\
\hline Non-Islam & 15.7 & 35.9 & 1.1 & 1.2 & 7.5 \\
\hline
\end{tabular}

Vonis "menista agama" terbukti memiliki konsekuensi elektoral yang sangat negatif bagi Ahok-Djarot. Di kalangan pemilih yang puas tapi mengurungkan niatnya memilih Ahok, 73,5 persen menganggap pidato Ahok tersebut sebagai penistaan (Tabel 3). Ini berarti mereka mengabaikan alasan rasional sematamata karena terluka atas pernyataan Ahok dalam kasus Al-Maidah. Insiden yang mengharu-biru jagat politik Indonesia pada 2016-2017 tersebut membuat merekaenggan menerjemahkan apresiasi atas kinerja Ahok dalam bentuk dukungan elektoral. Bahkan di basis anti-Ahok, yakni mereka yang tidak puas dan tak sudi memilih, hampir seluruhnya menilai pidato Ahok soal Al-Maidah sebagai penodaan agama. Ini bukti bahwa Al-Maidah adalah motor utama di balik kemenangan Anies. Sebaliknya, di kelompok pemilih loyal Ahok yang puas dan memilihnya, mayoritas menilai ucapan Ahok tidak menista agama. Hasil putaran kedua ini, sekali lagi, menunjukkan bahwa aspek rasionalitas tak seluruhnya bisa menjelaskan perilaku pemilih.

Dilihat dari afiliasi politik, Tabel 3 menunjukkan bahwa 45,7 persen pemilih yang puas tapi tidak memilih Ahok berasal dari warga Jakarta yang mencoblos pasangan Jokowi-Ahok pada pilkada 2012. Terbukti insiden Al-Maidah melucuti sikap partisan mereka. Pemilih Fauzi Bowo-Nachrowi Ramli solid menjadi pendukung kelompok anti-Ahok. Pola yang sama terjadi di kalangan pemilih Jokowi-Jusuf Kalla dan Prabowo-Hatta dalam pilpres 2014. Benar 
bahwa sebagian pemilih lama Jokowi-Ahok dan Jokowi-Kalla masih loyal terhadap Ahok, tapi mereka tak lagi nyaman karena mobilisasi politik identitas pasca-kasus Al-Maidah. Basis utama kelompok yang tidak puas terhadap kinerja Ahok dan pemilih Anies berasal dari pendukung Prabowo-Hatta. Tapi proporsi pemilih Jokowi-Kalla yang bocor ke Anies terhitung signifikan, terlepas dari kepuasan mereka terhadap petahana.

\section{Tabel 3: Kasus Al-Maidah dan Pilihan Elektoral di Pilkada 2012} dan Pilpres 2014

\begin{tabular}{|c|c|c|c|c|c|}
\hline & Base & $\begin{array}{l}\text { Puas, } \\
\text { pilih Ahok }\end{array}$ & $\begin{array}{c}\text { Puas, } \\
\text { tidak pilih } \\
\text { Ahok }\end{array}$ & $\begin{array}{c}\text { Tidak } \\
\text { puas, } \\
\text { tidak pilih } \\
\text { Ahok }\end{array}$ & $\mathrm{TT} / \mathrm{TJ}$ \\
\hline & & 41.5 & 30.1 & 26.4 & 2.1 \\
\hline \multicolumn{6}{|c|}{ SIKAP TERHADAP UCAPAN AHOK } \\
\hline $\begin{array}{l}\text { Ucapan Basuki Tjahaja Purnama (Ahok) } \\
\text { menistakan agama }\end{array}$ & 53.2 & 11.6 & 73.5 & 92.2 & 65.1 \\
\hline $\begin{array}{l}\text { Ucapan Basuki Tjahaja Purnama (Ahok) } \\
\text { tidak menistakan agama }\end{array}$ & 32.0 & 65.2 & 14.4 & 2.5 & 21.7 \\
\hline Tidak tahu & 14.8 & 23.2 & 12.1 & 5.3 & 13.3 \\
\hline \multicolumn{6}{|c|}{ PILGUB 2012 (PUTARAN 2) } \\
\hline Fauzi Bowo dan Nachrowi Ramli & 28.4 & 4.2 & 33.6 & 60.8 & 24.7 \\
\hline $\begin{array}{l}\text { Joko Widodo dan Basuki Tjahaja } \\
\text { Purnama (Ahok) }\end{array}$ & 53.6 & 80.1 & 45.7 & 21.7 & 43.8 \\
\hline Tidak ikut memilih/rahasia/tidak jawab & 18.0 & 15.7 & 20.7 & 17.5 & 31.4 \\
\hline \multicolumn{6}{|c|}{  } \\
\hline Prabowo Subianto dan Hatta Rajasa & 35.1 & 7.5 & 39.9 & 71.4 & 53.9 \\
\hline Joko Widodo dan M. Jusuf Kalla & 51.7 & 79.8 & 45.6 & 16.7 & 26.4 \\
\hline Tidak ikut memilih/rahasia/tidak jawab & 13.2 & 12.6 & 14.5 & 11.9 & 19.7 \\
\hline
\end{tabular}

Segmen pemilih yang puas tapi tidak memilih Ahok ini sebenarnya sudah terdeteksi sebelum meledaknya kasus Al-Maidah. Pada survei Indikator Mei and Juni 2016, beberapa bulan sebelum kasus ini meledak pada September, 27,1 persen warga Jakarta mengaku puas terhadap Ahok tapi sulit memilihnya di pilkada. Profil demografi mereka mirip dengan hasil exit poll, dan saat itu 72 persen responden yang masuk kategori puas tapi tak memilih menyatakan "sangat atau cukup setuju" dengan pernyataan bahwa "seorang pemimpin harus memiliki agama yang sama dengan saya." Dengan kata lain, bahkan sebelum AlMaidah meledak pun, Ahok sudah menghadapi ancaman kekalahan karena politik identitas.

Ini bukan berarti kasus Al-Maidah tidak berkontribusi terhadap kekalahan dramatis Ahok. Kasus ini menaikkan segmen pemilih yang puas tapi tidak memilih dari 27,1 persen di Mei-Juni 2016 menjadi 30,1 persen pada April 2017. Selain itu, mobilisasi Islamis pasca-pidato kontroversial tersebut juga 
memberi bahan bakar bagi penurunan citra Ahok di mata warga Jakarta. Kelompok pemilih yang puas dan bersedia memilih Ahok turun signifikan dari 49,4 persen di Juni 2016 menjadi 41,5 persen di hari pemilihan. Sedangkan basis anti-Ahok yang tak puas dan tak memilihnya naik dari 18,7 persen ke 26,4 persen pada periode yang sama. Ini sekali lagi bukti keras bahwa politik identitas yang berbasis primordial berperan penting dalam menentukan hasil akhir di pilkada Jakarta.

\section{Politik Identitas di Indonesia}

Jika politik identitas berbasis agama menjadi prediktor yang signifikan dalam pilkada Jakarta, bagaimana dengan wilayah lain di Indonesia? Bagaimana pula dengan efek etnik dalam menjelaskan perilaku pemilih, mengingat politik identitas bukan hanya dipicu oleh kesamaan agama tapi bisa saja karena kesamaan etnik? Indonesia adalah negara yang terdiri dari ratusan suku, namun studi selama ini menunjukkan lemahnya faktor kesukuan dalam menjelaskan politik elektoral (Aspinall, 2011; Liddle dan Mujani, 2007). Secara nasional, banyak ahli yang telah menyatakan bahwa efek etnik kecil dalam menjelaskan hasil pemilu legislatif dan pemilu presdien (Liddle and Mujani 2010; Mujani et al., 2011). Mujani dan kawan-kawan (2011) juga lama menegaskan minimnya efek agama dalam pemilu presiden sejak 2004. Meskipun politik identitas bukan faktor yang relevan secara nasional, efek politik primordial di tingkat lokal masih sedikit yang kita ketahui.

Untuk itu, di bagian akhir tulisan ini saya akan menyajikan hasil analisis berdasarkan survei-survei lokal yang representatif di lima provinsi yang heterogen, baik secara etnik maupun agama, yakni Sumatera Utara, DKI Jakarta, Kalimantan Barat, Sulawesi Utara and Maluku (Tabel 4 dan 5). Berbeda dengan pembahasan Jakarta di atas yang hanya berdasarkan pada Pilkada 2017 saja, pada bagian ini saya akan membahas dinamika politik identitas dengan membandingkan dari pilkada ke pilkada, dengan pasangan calon (paslon) yang berbeda-beda.

Dalam kasus Jakarta misalnya, saya akan menyajikan hasil analisis berdasarkan Pilkada Jakarta tahun 2012. Jadi kita bisa memperoleh gambaran menyeluruh kapan politik identitas bekerja dan kapan tidak. Metodologi yang digunakan adalah multi-stage random sampling. Jumlah sampel bervariasi antara 800 to 1000 respondendi setiap provinsi. Toleransi kesalahan (margin of error) dengan asumsi simple random sampling sampel 800 responden sebesar +- 3,5 persendan +- 3,1 
persen untuk sampel sebanyak 1000 responden pada tingkat derajat kepercayaan 95 persen. Wawancara dilakukan secara tatap muka oleh tim pewawancara yang sudah terlatih. Data yang dianalisis berdasarkan survei-survei yang dilakukan beberapa minggu sebelum pilkada, sehingga diasumsikan pemilih sudah mengetahui identitas etnik dan agama masing-masing calon gubernur dan wakil gubernur.

Tabel 4: Komposisi Etnik di Tiap Provinsi (\%)

\begin{tabular}{|l|c|}
\hline \multicolumn{1}{|c|}{ Sumate ra Utara } & Sen sus 2000 \\
\hline Jawa & 32.6 \\
\hline Batak, Tapanuli & 15.9 \\
\hline Toba & 9.7 \\
\hline Mandailing, Ankola Manda & 7.9 \\
\hline Nias, Kono Niha & 6.4 \\
\hline Karo & 5.1 \\
\hline Melayu & 4.9 \\
\hline Angkola & 3.4 \\
\hline Lainnya & 14.1 \\
\hline TOTAL & 100.0 \\
\hline
\end{tabular}

\begin{tabular}{|l|c|}
\hline \multicolumn{1}{|c|}{ Sulawesi Utara } & Sensus 2010 \\
\hline Minahasa & 45.0 \\
\hline Gorontalo & 8.3 \\
\hline Bugis & 1.0 \\
\hline Makas sar & 0.5 \\
\hline Suku Sulawesi lainnya & 38.9 \\
\hline Jawa & 3.1 \\
\hline Lainny a & 3.3 \\
\hline Total & 100 \\
\hline
\end{tabular}

\begin{tabular}{|l|c|}
\hline \multicolumn{1}{|c|}{ DKI JAKARTA } & Sensus 2000 \\
\hline Jawa & 35.2 \\
\hline Betawi & 27.6 \\
\hline Sunda, Priangan & 15.3 \\
\hline Tionghwa & 5.5 \\
\hline Batak, Tapanuli & 3.6 \\
\hline Minangkabau & 3.2 \\
\hline Melayu & 1 \\
\hline Melayu Palembang & 0.6 \\
\hline Lainny a & 8 \\
\hline TOTAL & 100 \\
\hline
\end{tabular}

\begin{tabular}{|l|c|}
\hline \multicolumn{1}{|c|}{ Kalimantan Barat } & Sensus 2000 \\
\hline Sambas & 11.9 \\
\hline Tionghwa & 9.5 \\
\hline Jawa & 9.1 \\
\hline Kendayan, Kenayan & 7.8 \\
\hline Melayu Pontianak & 7.5 \\
\hline Darat & 7.4 \\
\hline Madura & 5.5 \\
\hline Pesaguan & 4.8 \\
\hline Lainnya & 36.5 \\
\hline TOTAL & 100.0 \\
\hline
\end{tabular}

\begin{tabular}{|l|c|}
\hline \multicolumn{1}{|c|}{ Malu ku } & Sen sus 2000 \\
\hline Kei & 11.0 \\
\hline Buton, Butung, Butong & 10.6 \\
\hline A mbon & 10.5 \\
\hline Seram & 6.9 \\
\hline Saparua & 5.9 \\
\hline Jawa & 4.7 \\
\hline A ru & 4.2 \\
\hline Y amdena & 3.4 \\
\hline Lainny a & 42.8 \\
\hline TOTAL & 100.0 \\
\hline
\end{tabular}

Tabel 4 di atas menunjukkan tak ada satupun suku yang dominan di lima wilayah yang distudi. Selain multi-etnik, komposisi agama juga lebih beragam. Pemeluk non-Islam di lima provinsi tersebut lebih besar dari rata-rata nasional. Bahkan di Sulawesi Utara, Kristen Protestan adalah mayoritas. Di Maluku, warga terbelah antara Muslim yang mencapai 50,6 persen dibanding Kristen yang total mencapai 48,2 persen. Di Sumatera Utara dan Kalimantan Barat, meskipun Muslim adalah mayoritas, proporsi warga yang menganut agama selain Muslim tidaklah kecil. Jadi kelima provinsi tepat untuk dipilih sebagai studi kasus untuk menguji seberapa kuat pengaruh politik identitas dalam menjelaskan pilihan politik di tingkat lokal. 
Tabel 5: Afiliasi Agama di Tiap Provinsi (\%)(Sensus BPS 2010)

\begin{tabular}{|l|c|c|c|c|c|}
\hline & Sumatera Utara & $\begin{array}{c}\text { Kalimantan } \\
\text { Barat }\end{array}$ & Sulawesi Utara & Maluku & Jakarta \\
\hline Islam & 66.1 & 59.2 & 30.9 & 50.6 & 85.4 \\
\hline Protestan & 27.0 & 11.4 & 63.6 & 41.4 & 7.5 \\
\hline Katolik & 4.0 & 22.9 & 4.4 & 6.8 & 3.2 \\
\hline Hindu & 0.1 & 0.1 & 0.6 & 0.4 & 0.2 \\
\hline Budha & 2.3 & 5.4 & 0.1 & 0.0 & 3.3 \\
\hline Konghucu & 0.0 & 0.7 & 0.0 & 0.0 & 0.1 \\
\hline Lainnya & 0.0 & 0.1 & 0.1 & 0.4 & 0.0 \\
\hline Tidak ditany akan & 0.4 & 0.2 & 0.3 & 0.4 & 0.3 \\
\hline
\end{tabular}

Untuk mengetahui signifikansi efek etnis dan agama dalam menjelaskan elektabilitas pasangan calon gubernur dan wakil gubernur di lima provinsi di atas, saya membuat dua jenis analisis: analisis bivariat dan multivariat dengan menggunakan model logistik (biner atau multinomial). Dalam analisis bivariat, variabel yang diuji hanya etnis atau agama. Saya mengetes apakah kesamaan agama atau etnik antara pemilih dengan calon gubernur atau wakil gubernur memiliki dampak elektoral atau tidak. Sedangkan dalam analisis multivariat, variabel etnis dan agama tersebut dikontrol dengan faktor-faktor lain yang biasanya menjadi prediktor dalam menjelaskan perilaku memilih, seperti agama, gender, usia, desa-kota, tingkat pendidikan, kepuasan terhadap kinerja petahana, party ID, kualitas personal calon, dan sosialisasi calon. Kepuasan terhadap petahana diukur melalui seberapa puas responden terhadap kinerja petahana. Kualitas personal diuji dengan menanyakan kepada responden apakah para calon yang berlaga di pilkada dianggap jujur atau bersih dari korupsi, perhatian kepada rakyat, tegas atau berwibawa, dan mampu memimpin atau tidak. Terakhir, variabel sosialisasi diukur sejauhmana responden terekspos media sosialisasi atau kampanye para calon, entah itu melalui bertemu langsung, poster, spanduk dan lain-lain.

Mari kita mulai pembahasan dari Sulawesi Utara. Tiga paslon gubernur dan wakil gubernur maju bertarung dalam pilkada 2015: Paslon Olly Dondokambey dan Steven Kandouw sama-sama Kristen Protestan dan keduanya bagian dari suku mayoritas Minahasa. Paslon Maya Rumantir dan Glenny Kairupan juga orang asli Minahasa, tapi Maya beragama Katolik yang jumlahnya sedikit di 
Sulawesi Utara berpasangan dengan Glenny yang beragama Protestan dan berlatar belakang militer. Adapun paslon Benny Mamoto dan David Bobihoe memiliki latar belakang etnik dan agama yang berbeda: Benny adalah Kristen Minahasa, sedangkan David adalah Gorontalo Muslim.

Analisis bivariat menunjukkan bahwa factor etnik memiliki efek signifikan dalam menjelaskan elektabilitas ketiga paslon di Sulawesi Utara pada pilgub 2015. Namun, ketika saya masukkan seluruh variable kontrol, koefisien etnik kehilangan signifikansinya $(0,05)$. Sebaliknya, afiliasi agama paslon dan kualitas personalnya memainkan peran yang signifikan dalam menentukan hasil akhir pilkada. Analisis multivariat berdasarkan sigi jelang pemilihan gubernur di Sulawesi Utara tahun 2010 menunjukkan pola yang sama: efek suku terhadap pilihan hilang setelah dikontrol variabel-variabel lainnya, sedangkan efek agama tetap signifikan. Variabel dependennya adalah pilihan pasangan calon dengan reference category pilihan pada Benny-David. Analisis regresi logistik multinomial menunjukkan bahwa pemilih Kristen cenderung lebih memilih Olly-Steven dan Maya-Glenny dibanding Benny-David, terlepas dari kondisi gender, desakota, usia, pendidikan, evaluasi atas kinerja pemerintah, penilaian terhadap kualitas calon, maupun identitas partainya.

Tidak signifikannya etnik ini mungkin disebabkan oleh fakta bahwa seluruh calon gubernur yang maju pada pilkada Sulawesi Utara berasal dari suku Minahasa. Selain itu, sebagaimana dijelaskan di Tabel 4 di atas, komposisi etnik di provinsi ini relative tidak terlalu imbang. Meskipun banyak sekali etniketnik kecil seperti Sangir, Bolang Mangandow, etnik Minahasa terlalu dominan (45 persen). Hal ini berbeda dengan agama; meski Kristen Protestan mayoritas, jumlah Muslim cukup signifikan di provinsi ini. Apalagi David Bobihoe merupakan satu-satunya calon (baca: calon wakil gubernur) yang beragama Muslim.

Kalimantan Barat menunjukkan pola yang mirip dengan Sulawesi Utara: efek agama jauh lebih kuat dan konsisten dibanding etnik dalam menjelaskan pilihan. Pada pilkada 2012 di Kalimantan Barat, sebagian besar calon gubernur yang berlaga menggandeng pasangan dari suku yang berbeda (Dayak dan Melayu, atau Dayak dan Tionghwa), kecuali Morkes Effendi dan Burhanuddin Rasyid yang keduanya berasal dari Melayu Muslim. Calon petahana saat itu, Cornelis, Katolik Dayak, berpasangan dengan Christiandy, Tionghwa Protestan. Paslon ini memakai strategi lama dengan memaksimalkan dukungan dari kalangan Kristen yang mencapai 35 persen dari populasi pemilih Kalimantan Barat. 
Suara Islam, meskipun dominan, terbelah karena diperebutkan tiga paslon lainnya.

Analisis bivariat lagi-lagi menunjukkan hubungan yang signifikan antara faktor etnik dengan elektabilitas paslon. Namun korelasi dua variabel ini ternyata semu: efek etnik mengendur setelah dikontrol variabel-variabel lainnya. Menariknya, efek agama tetap signifikan menjelaskan pilihan di pilkada Kalimantan Barat tahun 2012, terlepas dari kondisi gender, desakota, usia, pendidikan, evaluasi atas kinerja pemerintah, penilaian terhadap kualitas calon, maupun identitas partainya. Dalam analisis regresi multinomial, reference category-nya adalah elektabilitas Cornelis-Christiandy. Pemilih Muslim, apapun etniknya, cenderung memilih tiga paslon lainnya yang beragama Muslim ketimbang Cornelis-Christiandy. Sebaliknya, pemilih Kristen-Katolik solid memilih Cornelis-Christiandy. Kuatnya efek agama dibanding etnik juga terjadi di pilkada tahun 2007 di Kalimantan Barat. Paslon Cornelis-Christiandy juga memonopoli dukungan suara Kristen dibanding tiga paslon lainnya yang memperebutkan pangsa pasar yang sama: Muslim. Perbedaannya, pada tahun 2012, selain efek agama, penilaian terhadap performa Cornelis sebagai petahana juga berpengaruh signifikan terhadap keputusan memilih calon gubernur-wakil gubernur.

Di pilkada Maluku tahun 2013, dua paslon maju ke putaran kedua: Said Assagaf dan Eti Sahuburua versus Abdullah Vanath dan Martin Maspaitella. Assagaf adalah seorang Muslim dan wakil gubernur petahana, sedangkan pasangannya (Eti) beragama Christian dan berasal dari Ambon. Assagaf adalah keturunan Arab, tapi keluarganya lama berdomisili di Pulau Banda dan Ambon. Dia menikah dengan seorang perempuan asal Sulawesi, sehingga membantu Assagaf dalam menarik simpati dari warga Sulawesi yang tinggal di Maluku (dikenal dengan akronim BBM: Bugis, Butondan Makassar), yang menguasai sendi perekonomian di provinsi ini. Sementara Abdullah Vanath adalah bupati dua periode di Seram Bagian Timur, sedangkan Marthin Maspaitella adalah tokoh intelektual muda Kristen asli dari kota Ambon.

Analisis bivariat dan multivariat menunjukkan hasil yang konsisten: efek etnik dan agama sama-sama menentukan hasil pilkada di Maluku pada 2013. Menariknya, analisis regresi multivariat menunjukkan bahwa dibanding Abdullah, Assagaf sedikit lebih sukses menggaet dukungan dari pemilih Muslim. Padahal keduanya sama-sama beragama Islam dan sama-sama menggandeng pasangan beragama Kristen. Bisa jadi faktor keturunan Arab membantu Assagaf 
dalam menarik simpati pemilih Muslim. Di samping itu, variabel kedekatan terhadap partai-partai pengusung paslon, penilaian terhadap kualitas personal calon, dan sosialisasi kampanye juga signifikan menjelaskan perilaku pemilih di Maluku. Namun demikian, kepuasan terhadap kinerja Assagaf sebagai wakil gubernur tidak signifikan mempengaruhi elektabilitas paslon. Pada pilkada Maluku di 2008, pengaruh etnik sangat terbatas. Sebaliknya, faktor agama justru berpengaruh signifikan.

Di Sumatera Utara, lima paslon gubernur dan wakil gubernur bertarung di Pilkada 2013. Effendi Simbolonyang berlatar Kristen dan Batak Toba meminang Jumiran Abdi yang Muslim dari suku Jawa. Gus Irawan Pasaribu yang merupakan Batak Muslim berpasangan dengan Sukirman Muslim keturunan Jawa. Penjabat gubernur sementara Gatot Pujo Nugroho sendiri seorang keturunan Jawa yang mengajak seorang birokrat asli Melayu,Tengku Erry Nuradi. Meski berasal dari suku yang berbeda, keduanya beragama Muslim. Demikian pula dengan paslon Chairuman Harahap dan Fadly Nurzal yang berasal dari latar belakang etnik berbeda tapi sama-sama Muslim. Sebaliknya, paslon Amri Tambunan dan RE Nainggolan sama-sama orang Batak Toba, tapi keduanya memiliki identitas agama yang berbeda.

Analisis bivariat menunjukkan hubungan signifikan antara etnik dengan elektabilitas calon. Demikian juga variabel agama. Namun ketika diuji melalui analisis regresi multinomial dengan elektabilitas Gatot-Tengku sebagai reference category, efek etnik memiliki pengaruh yang terbatas pada pilkada 2013. Faktor etnik hanya berpengaruh signifikan jika dibandingkan dengan Gus IrawanSukirman, sementara dibanding paslon lainnya tidak signifikan. Pemilih Jawa cenderung memilih Gatot-Tengku ketimbang Gus Irawan-Sukirman. Sebaliknya, pemilih Batak Toba cenderung memilih Gus Irawan-Sukirman dibanding Gatot-Tengku. Adapun faktor agama juga hanya berpengaruh signifikan dalam menjelaskan elektabilitas Gatot-Tengku versus Amri-Rustam dan antara GatotTengku versus Effendi-Jumiran. Intinya, pemilih Muslim cenderung memilih pasangan Gatot-Tengku ketimbang paslon Amri-Rustam dan Effendi-Jumiran. Sebaliknya, umat Kristiani cenderung memilih Amri-Rustam dan EffendiJumiran dibanding Gatot-Tengku. Ini karena Effendi dan Rustam adalah seorang Kristiani, sedangkan Gatot seorang Muslim. Efek agama kurang berpengaruh dalam menjelaskan elektabilitas paslon Gatot-Tengku dibanding paslon Chairuman-Fadly dan Gus Pasaribu-Sukirman karena ketiga paslon berlatar belakang agama yang sama (Muslim). Pada pilgub 2008, efek etnik juga terbatas. Namun demikian, pengaruh agama signifikan menjelaskan perilaku 
pemilih pada saat itu, tergantung komposisi agama paslon masing-masing. Efek agama muncul ketika paslon dibandingkan paslon lain yang berbeda agama.

Studi kasus terakhir yang kita uji adalah pilkada DKI Jakarta tahun 2012. Dua paslon bertarung pada saat itu. Pertama, Fauzi Bowo dan Nachrowi Ramli yang sama-sama berasal dari Betawi. Fauzi adalah gubernur petahana yang meminang Nachrowi, mantan jenderal. Sedangkan lawannya adalah Joko Widodo (Jokowi) yang asli dari Jawa dan berpasangan dengan politisi yang berlatar belakang Kristen Tionghwa,Ahok. Hasil analisis bivariat dan multivariat menunjukkan pengaruh etnik signifikan menjelaskan elektabilitas paslon. Pemilih Jawa and China cenderung memilih Jokowi-Ahok dibanding Fauzi-Nachrowi. Sebaliknya, pemilih Betawi cenderung memilih Fauzi-Nachrowi dibanding Jokowi-Ahok. Tapi etnik bukanlah satu-satunya faktor determinan. Pengaruh usia, tingkat pendidikan, kepuasan terhadap kinerja Fauzi sebagai petahana, kualitas personal calon dan sosialisasi juga signifikan menjelaskan perilaku pemilih warga Jakarta pada 2012. Semakin muda pemilih dan semakin tinggi tingkat pendidikan mereka, maka semakin cenderung memilih Jokowi-Ahok. Selain itu, semakin tidak puas mereka terhadap kinerja Fauzi dan semakin baik citra personal Jokowi, maka pemilih cenderung memilih Jokowi ketimbang Fauzi. Begitu juga sebaliknya. Uniknya, pengaruh suku yang sangat dominan menjelaskan pilihan warga Jakarta pada Pilkada 2012 dan Pilkada 2007 (Prasetyawan, 2014) hilang tertelan faktor agama pada pilkada terakhir di 2017, sebagaimana telah dijelaskan di atas. Pada pilkada 2007 dan 2012, agama tak pernah menjadi prediktor yang signifikan di Jakarta.

Agama merupakan faktor yang penting dalam pemilihan gubernur dan wakil gubernur, khususnya ketika ada perbedaan agama antar paslon. Ini terlihat di Jakarta, Sumatera Utara, Kalimantan Barat dan Sulawesi Utara. Studi ini menunjukkan kecenderungan pemilih untuk memilih calon yang agamanya sama dengan mereka. Pengaruh agama dalam politik elektoral di tingkat lokal terlihat sangat meyakinkan. Dalam analisis multivariat, faktor agama tetap signifikan ketika dikontrol oleh faktor-faktor lain (etnis, gender, desakota, umur, tingkat pendidikan, evaluasi atas kinerja pemerintah, identitas partai, maupun penilaian terhadap kualitas calon). Pada Pilkada Jakarta 2007 dan 2012, efek agama tidak signifikan. Namun hal tersebut tidak otomatis membatalkan efek agama dalam politik elektoral. Pada saat itu tidak ada perbedaan agama antar calon gubernur dan tidak ada insiden Al-Maidah, sehingga tidak memungkinkan bagi munculnya efek agama. Jika muncul paslon 
yang beragama berbeda (cross-religious pairs), sebagian besar pemilih cenderung melihat agama calon gubernur ketimbang identitas primordial pasangannya.

Faktor etnis juga penting, tetapi pengaruhnya memiliki keterbatasan, terutama ketika dikontrol oleh faktor-faktor lain. Di Maluku, ketika dikontrol oleh faktorfaktor lain, pengaruh etnis tetap signifikan. Namun di banyak kasus, pengaruh etnis menjadi tidak signifikan ketika dikontrol oleh faktor-faktor lain. Secara umum, efek agama jauh lebih kuat dan konsisten ketimbang etnik. Pengaruh etnik tetap signifikan jika para paslon yang berlaga berasal dari agama yang sama, seperti Pilkada Jakarta tahun 2007 dan 2012 dan Pilkada Maluku 2013. Di Pilkada Jakarta tahun 2012, Fauzi Bowo dan Jokowi sama-sama Muslim, sehingga mobilisasi identitas yang coba digunakan di putaran kedua saat itu kurang berpengaruh. Ketika perbedaan agama tak bisa dieksploitasi, perbedaan etnik bisa dimobilisasi untuk mendapatkan keuntungan elektoral. Dengan demikian, efek agama dan etnik bersifat dinamis, tergantung konteks sosialpolitik dan kondisi persaingan dan latar belakang primordial paslon.

\section{Penutup}

Secara umum, penelitian ini telah menemukan bukti empiris bahwa agama dan etnis yang menjadi bahan bakar politik identitas merupakan faktor yang penting dalam pemilihan kepala daerah. Saya juga sudah membuktikan bahwa politik identitas sudah lama terjadi di tingkat lokal, jauh sebelum kasus Pilkada Jakarta 2017. Politik identitas bekerja terutama ketika komposisi etnik dan agama suatu wilayah tidak terlalu timpang dan tergantung identitas primordial para paslon yang bertarung. Calon yang berasal dari kelompok agama dan suku mayoritas punya modal yang lebih baik dalam berkompetisi dibanding calon yang berasal dari kelompok minoritas. Ini menjelaskan mengapa Ahok kalah di Pilkada Jakarta tahun 2017, meskipun approval rating-nya tinggi. Namun paslon dari kelompok agama atau etnik minoritas bisa menang jika lawannya yang berasal dari kelompok mayoritas terbelah. Ini terjadi di Kalimantan Barat ketika Cornelis sukses mengalahkan para kompetitornya di 2007 and 2012. Suara Muslim yang mayoritas terbagi ke tiga paslon, sedangkan Cornelis memobilisasi basis non-Muslim dari suku Dayak dan China yang selama ini termarginalkan oleh etnik Melayu yang Muslim.

Perilaku memilih merupakan gejala yang kompleks. Keputusan memilih ditentukan oleh banyak faktor. Seorang calon yang berasal dari kelompok identitas primordial tertentu belum tentu dapat menarik suara mayoritas di 
kelompoknya sendiri. Hal ini bisa terjadi karena, selain faktor identitas, pemilih juga mempertimbangkan faktor-faktor lain, terutama kualitas personal calon. Intinya, dinamika politik lokal seringkali membuka ruang mobilisasi politik identitas. Pilkada Jakarta hanya sedikit contoh di mana perilaku pemilih bukan semata-mata didasarkan pada rasionalitas pemilih. Jika pemilih Jakarta rasional, seharusnya kepuasan terhadap kinerja petahana diterjemahkan dalam bentuk pilihan. Apalagi warga Jakarta memiliki modal rasionalitas yang lebih baik ketimbang wilayah lain dilihat dari tingkat pendidikan dan pendapatan serta akses terhadap informasi. Ternyata kinerja baik saja tak cukup mengantarkan pada kemenangan. Tentu naif berharap kontestasi elektoral kita akan sepi dari mobilisasi politik identitas berbasis isu-isu abad pertengahan. Tapi ikhtiar kita tak boleh berhenti dalam mendorong calon pejabat publik agar berorientasi program dan memakai pendekatan rasional dalam meyakinkan pemilih [] 